\title{
FILSAFAT SEJARAH HAMKA: Refleksi Islam dalam Perjalanan Sejarah
}

\author{
Fabian Fadhly Jambak \\ Universitas Islam Negeri Sunan Gunung Djati Bandung \\ e-mail: fabianfadhly@ymail.com
}

\begin{abstract}
Understanding of the historiography of HAMKA cannot be separated from the understanding of the three elements that underlies his historical philosophy of the history of Muslims of the 13th century AD. The three elements that form the basis of the historical philosophy of HAMKA are tawheed (tawhīd), moral (akhläq) and intelligence ('aql). This paper intends to reveal the historical philosophy of HAMKA and its underlying elements. The method used in this paper is a normative method with an analytical approach. Normative is used to describe and narrate the views of the historical philosophy of HAMKA, which is influenced by various views of his life reflected through his literature (sastra), tafsir, and history (historiography). Analytical is used to provide views or responses related to the points of thought within the scope of historical philosophy. This study finds that Historical Philosophy of HAMKA affirms that tawheed, moral, and intelligence are inseparable part of seeing an event which became known as history. Tawheed is shown by the human resignation as God's creature that the events that happen to him are the proper circumstances. Intelligence shows the character of man as a being who can contemplate every event that occurs in his life. Moral leads man to understand that an event is not only determined by the side of Tawheed and Intelligence, but also by the Morals who have a function to regulate human behavior how it should behave in every historical event, with the intention to acquire ibrah (lesson).
\end{abstract}

Abstrak: Pemahaman terhadap historiografi HAMKA tidak dapat dilepaskan dari pemahaman tiga unsur yang mendasari filsafat sejarahnya tentang sejarah umat Islam abad 13-20 Masehi. Tiga unsur yang menjadi dasar filsafat sejarah HAMKA yaitu tauhid, akhlak dan akal. Tulisan ini bermaksud untuk mengungkap filsafat sejarah HAMKA beserta unsur-unsur yang mendasarinya. Metode yang digunakan dalam tulisan ini adalah metode normatif dengan pendekatan analitis. Normatif digunakan untuk memberikan gambaran dan menarasikan pandangan-pandangan filsafat sejarah HAMKA, yang dipengaruhi oleh berbagai macam pandangan hidupnya yang tercermin melalui karya satra, tafsir dan sejarahnya (historiografi). Analitis digunakan untuk memberikan pandangan atau tanggapan terkait pokok-pokok pikirannya dalam ruang lingkup filsafat sejarah. Kajian ini menemukan bahwa filsafat sejarah HAMKA meneguhkan bahwa tauhid, akhlak, dan akal merupakan bagian yang tidak terpisahkan dalam melihat suatu peristiwa yang kemudian dikenal dengan sejarah. Tauhid ditunjukkan dengan keberserahan manusia sebagai makhluk Allah bahwa peristiwa yang terjadi kepadanya merupakan keadaan yang semestinya terjadi. Akal menunjukkan ciri manusia sebagai mahkluk yang dapat merenungi setiap peristiwa yang terjadi dalam kehidupannya. Akhlak mengarahkan manusia untuk memahami 
bahwa suatu peristiwa tidak hanya ditentukan oleh sisi Tauhid dan Akal, melainkan juga oleh Akhlak yang memiliki fungsi untuk mengatur perilaku manusia bagaimana seharusnya bersikap dalam setiap peristiwa sejarah, dengan maksud untuk memeperoleh ibrah (pelajaran).

Keywords: filsafat sejarah; philosophy of history; HAMKA

\section{A. Pendahuluan}

Sejarah perjalanan Islam sebagai ajaran ketuhanan dan kemanusiaan yang tidak dapat dilepaskan dengan umat Islam. Peradaban dan kebudayaan yang terus berkembang mengenai Islam selalu diikuti oleh umat Islam sebagai subjek atau pelaku dari sejarah Islam itu sendiri. Islam memiliki sejarahnya sendiri, yang berjalan beriringan dengan umat Islam diawali dari lahirnya Nabi dan Rasul terakhir dari kalangan Quraisy, yaitu Nabi Muhammad yang lahir dari kesucian nasab (garis keturunan) yang dimilikinya. Karakteristik ini muncul mulai dari 'Abd al-Muthalib dengan nasab bersambung kepada Zuhrah ibn Kilab, sebagai pemuka kaum Bani Zuhrah yang memiliki kemuliaan sebagai pemimpin pada saat itu. Kesucian nasab dari Nabi Muhammad tidak terlepas dari pernikahan yang dilakukan oleh 'Abdullah sebagai keturunan dari 'Abd al-Muthalib dengan Aminah sosok wanita unggul dari kalangan suku Quraisy. ${ }^{1}$

Permulaan dari sosok mulia ini mengantarkan Islam menjadi sebuah kebudayaan dan peradaban, yang mempengaruhi berbagai belahan dunia baik timur maupun barat abad ke-7 M-19 M.2 Kemunculan dan perkembangan Islam

1Shalih Ahmad al-Tsamy, Min Ma'in al-Sirah (Beirut: al-Maktab al-Islamy, 1984), h. 17. Shafiyu al-Rahman al-Mubakafury merinci geneologis Nabi Muhammad menjadi tiga garis, garis pertama terkait dengan nasab Rasullah sampai dengan Adnan (Muhammad ibn 'Abdullah ibn 'Abd alMuthalib ibn Hayim ibn Abdi Manaf ibn Qushay ibn Kilab ibn Murrah ibn Nadra ibn Ka'ab ibn Luay ibn Ghalib ibn Fihr ibn Malik ibn Nadra ibn Kinanah ibn Khuzaimah ibn Mudkirah ibn Ilyas ibn Mudara ibn Nizar ibn Ma'add ibn Adnan. Garis kedua terkait dengan nasab Adnan sampai dengan Nabi Ibrahim as (Adnan Ibn Udad ibn Hamaysa' ibn Salaman ibn 'Aush ibn Bauz ibn Qumwal ibn Abi ibn 'Awam ibn Nasyad ibn Hazan ibn Bildas ibn Yudalaf ibn Thabikh ibn Jahim ibn Nahisy ibn Makha ibn 'Ayidh ibn Abqar ibn 'Ubaid ibn Da'an ibn Hamdan ibn Sinbar ibn Yatsrabi ibn Yahzan ibn Yalhan ibn Ar'awi ibn A'yidh ibn Daisyan ibn 'Ishar Ibnu Afnad ibn Ayham ibn Muqshar ibn Nahits ibn Zarah ibn Sama ibn Muza ibn 'Audlah ibn 'Aram ibn Qidar ibn Ismail ibn Ibrahim. Garis ketiga terkait dengan nasab Nabi Ibrahim sampai dengan Nabi Adam. (Ibrahim ibn Tarah ibn Nahur ibn Saru' (Sarugh) ibn Ra'u ibn Falah ibn 'Abir ibn Syalakh ibn Arfakhsyad ibn Sam ibn Nuh ibn Lamak ibn Matusyalakh ibn Akhnukh (Idris) ibn Yarda ibn Mahlail ibn Qinan ibn Anusy ibn Syits ibn Adam. Baca: Shafiyu al-Rahman al-Mubarakafury, Rahiq al-Makhtum Bahthun al-Sirah al-Nabawiyyah 'ala Șāhibuhā Afḍalu al-Ṣalātu wa '-Salām (al-Mansurah: Dar al-Wafa, , 2002), h. 63-64.

2Peradaban Islam mengalami kemunduran dimulai dari hancurnya Baghdad oleh Hulagu Khan pada tahun 1258 M. Kemunduran Islam sebagai sebuah peradaban dipengaruhi salah satunya oleh faktor disintegrasi politik yang memecah belah kekuatan dunia Islam menjadi berkepingkeping yang berujung pada jatuhnya kota Baghdad ibukota, dan pusat peradaban dan kebudayaan 
menjadi sebuah peradaban baru memberikan pengaruh sangat besar terhadap kebudayaan dan peradaban Islam, yang kemudian membentuk corak yang berbeda-beda sesuai penyebaran dan perkembangan di wilayah yang didatanginya. Kebudayaan dan peradaban Islam yang muncul di wilayah Eropa, akan berbeda dengan wilayah di Asia, Afrika, maupun di Amerika.

Proses penyebaran dan perkembangan Islam yang kemudian menjadi bagian dari akulturasi dengan budaya lokal merupakan pengungkapan bagaimana Islam menjadi jembatan dalam membentuk/menghasilkan kebudayaan dan peradaban baru. Islam yang bersinergi dengan model akulturasi menjadi salah satu yang menarik bagi HAMKA untuk ikut berperan dalam menarik runtutan sejarah (history chain). Memang, runtutan sejarah ini kemudian memunculkan berbagai macam tafsiran mengenai jalur dan alur perjalanan Islam menyinggahi dan menetap menjadi sebuah ajaran agama di suatu wilayah, baik ia menjadi minoritas seperti di wilayah Eropa dan Amerika maupun menjadi mayoritas di wilayah Asia terutama Asia Tenggara khususnya Indonesia.

HAMKA memulai dengan melihat kembali Islam sebagai sebuah realitas sejarah yang dibangun dari wilayah Hijaz yang memiliki kondisi daerah yang kering, dikelilingi oleh gunung yang tidak memberikan lingkungan untuk ditempati, serta memiliki temperatur suhu yang tinggi. Kondisi yang tidak menguntungkan bagi manusia untuk hidup ini tidak lantas Allah melepaskan kasih sayangnya untuk mengutus Nabi Muhammad sebagai Rasul terakhir yang membawa risalah tersebut. $^{3}$

Nabi Muhammad menjadi bagian terpenting dan paling awal untuk dijelaskan sebagai sosok yang memberikan pengaruh yang luas terhadap terbentuknya ummah. Sosok ini oleh HAMKA diuraikan secara menyeluruh; bagaimana Islam melalui tangan dan kepribadian khātim al-anbiy $\bar{a}^{\prime}$ ini bermula dan terus berkembang sampai ke wilayah Nusantara yang dikenal saat ini sebagai Indonesia. Penulisan (historiografi) yang dilakukan oleh HAMKA tidak hanya menulis tanpa berdasarkan epistemologis, aksiologis dan ontologis yang mengarahkan nilai-nilai filsafat yang terdapat di dalamnya. ${ }^{4}$

dunia Islam ke tangan bangsa oleh bangsa Mongol di bawah pimpinan Hulagu pada tahun 1258 M, yang membakar mayoritas karya besar produk intelektual muslim zaman klasik.

3Lihat: Firas al-Khateeb, Lost Islamic History Reclaiming Muslim Civilisation from the Past (London: Hurst Publisher, 2014), h. 1\& 10.

${ }^{4}$ Khusus bagi penulisan Islam di Indonesia HAMKA dalam melakukan penulisan Sejarah Umat Islam IV banyak bahannya yang diambil dari historiografi lokal meski bercampur dengan mitos dan legenda, seperti Hikayat Raja-raja Pasai, dan Sejarah Melayu yang menjelaskan interaksi langsung 
Pandangan filsafat sejarah HAMKA tidak mudah untuk diketahui atau dilacak. Kesulitan ini dikarenakan HAMKA memiliki kemampuan yang tidak hanya sebagai sejarawan melainkan pula sebagai sastrawan, ulama, pemikir pembaharuan Islam di Indonesia yang lekat dengan organisasi kemasyarakatan Muhammadiyah yang didirikan oleh Ahmad Dahlan tahun 1912 di Yogyakarta.

Filsafat sejarah HAMKA dapat ditemukan bila merujuk kepada teori Arabia yang dicetuskan sebagai dasar Islam masuk ke Indonesia bertepatan dengan abad ke-7 M atrau $1 \mathrm{H}$. HAMKA mengemukakan bahwa sejarah panjang Islam berada di Indonesia dimulai pada abad ke-7 $\mathrm{M}$ dengan berhijrahnya bangsa Arab melalui Samudera Hindia dan melalui jalan darat. Perkampungan-perkampungan yang didirikan oleh banga Arab menjadi bukti bahwa Islam telah masuk pada abad tersebut. Tempat singgah yang berada di rute perdagangan daerah Malabar dan pulau Sailan merupakan bukti Indonesia menjadi bagian dari perluasaan kekuasaan Bani Umayyah pada saat itu, melalui pendekatan ekonomi atau transaksi perniagaan. ${ }^{5}$

Yahya Harun mengungkapkan, HAMKA dalam pendekatan historiografinya lebih banyak menekankan kepada periode daripada daerah. Penekannya lebih banyak kepada peranan pahlawan dan Sultan dalam bangun dan tenggelamnya kerajaan Islam di kepulauan Nusantara, sehingga ia dikenal sebagai penulis sejarah heroworship. ${ }^{6}$ Pandangan Yahya Harun ini setidaknya menunjukkan bahwa HAMKA terbawa oleh model penulisan historiografi klasik seperti Kitab alBidāyah wa l-Nihāyah karya Ibnu Katsir, Kitab Tārikh al-Ṭabari karya al-Thabari, Kitab Tajārib al-Umām wa Ta'aqab al-Himām karya Abu 'Ali Ahmad ibn Muhammad ibn Ya'qub Miskawaih yang mengedepankan peran para sultan, Raja, Amir dalam membangun masyarakat Islam setelah meninggalnya Nabi Muhammad.

Tulisan ini dimaksudkan sebagai usaha untuk memberikan pemahaman dan pemaknaan yang tepat terhadap filsafat sejarah HAMKA yang tidak hanya

antara Nusantara dengan Arabia. Lihat: HAMKA, Sejarah Umat Islam IV (Jakarta: Bulan Bintang, 1976). Argumen ini didukung oleh Rosenthal Rosenthal, dalam melacak historiografi Islam awal di Indonesia, melihat bahwa bentuk dasar historiografi Islam di Indonesia adalah karya sastra klasik yang isinya banyak menyebutkan istilah-istilah kepada narasi tertentu seperti haba, hikayat, kisah, dan tambo yang berasal dari bahasa Arab. M. Yakub, "Historiografi Islam Indonesia: Perspektif Sejarawan Informal," MIQOT Vol. XXXVII No. 1 Januari-Juni 2013, h. 160. Lihat A. Muin Umar, Historiografi Islam (Jakarta: Rajawali Press, 1988), h. 188.

5HAMKA, Sejarah Umat Islam IV (Jakarta: Bulan Bintang, 1976), h. I38.

6M. Yakub, "Perkembangan Islam Indonesia”, Kalam, Volume 7, Nomor 1, Juni 2013, h. 139. Lihat: Yahya Harun, Islam Nusantara Abad XVI \& XVII (Yogyakarta: Kurnia Kalam Sejahtera 1995). 
memiliki perhatian yang besar terhadap Islam dan Umat Islam terutama di Indonesia, melainkan pula berupaya untuk mengembalikan Islam sebagai sebuah kebudayaan yang muncul, dibentuk, berkembang dan mapan sebagai suatu peradaban selama 12 abad sampai pada runtuhnya peradaban Islam oleh dua kekuatan yaitu bangsa Mongol dan kolonialisme Eropa di wilayah-wilayah berpenduduk muslim.

Metode yang dikedepankan dalam tulisan ini adalah metode normatif dengan pendekatan analitis. Normatif digunakan untuk memberikan gambaran dan menarasikan pandangan-pandangan filsafat sejarah HAMKA yang dipengaruhi oleh berbagai macam pandangan hidupnya yang dimunculkan melalui karya satra, tafsir dan sejarah (historiografi). Analitis digunakan untuk memberikan pandangan atau tanggapan terkait pokok-pokok pikiran HAMKA dalam ruang lingkup filsafat sejarah.

\section{B. Sekilas Biografi HAMKA}

Haji Abdul Malik Karim Amrullah (selanjutnya ditulis HAMKA) adalah putra seorang ulama besar Syekh Abdul Karim Amrullah atau yang sering disebut Haji Rosul. Haji Rosul adalah pelopor dari Gerakan Islam "Kaum Muda" di Minangkabau yang memulai gerakannya pada tahun $1908 . .^{7}$ Kelahiran dan kehidupan masa kecilnya sangat dipengaruhi oleh beberapa variabel lingkungan sosial. Pertama adalah peran sosial dan harapan-harapan ayahnya terhadap HAMKA. Kedua, kampung tempat dia dilahirkan. Ketiga, asimilasi adat Islam yang mempengaruhi masyarakat sekitarnya. HAMKA dibesarkan dalam lingkungan ulama, maka tidak heran apabila Haji Rosul menginginkan anaknya kelak menjadi seorang alim ulama seperti dirinya dan dikagumi banyak orang. ${ }^{8}$

HAMKA merupakan anak pertama dari tujuh bersaudara, ia sejak kecil hidup dalam keluarga yang taat melaksanakan ajaran agama Islam. ${ }^{9}$ Apabila ditelusuri dari silsilah nenek moyangnya, maka HAMKA termasuk keturunan orang-orang yang terpandang dan tokoh agama Islam pada zamannya. Dari

${ }^{7}$ Rusydi. Pribadi dan Martabat Buya Prof. Dr. HAMKA (Jakarta: Pustaka Panjimas, 1983), h.1.

8Sardiman, dkk, "Buya HAMKA dan Perkembangan Muhammadiyah (1925-1981)” Laporan Penelitian, Fakultas Ilmu Sosial Universitas Negeri Yogyakarta, 2012, h. 1.

${ }^{9}$ Mafri Amir dan Lilik Ummi Kultsum, Literarur Tafsir Indonesia, Lembaga Penelitian UIN Syarif Hidayatullah Jakarta, Ciputat, 2011, h.157. Buya HAMKA merupakan seorang sastrawan, sejarawan, dan ulama yang lahir pada tanggal 16 Februari 1908 bertepatan dengan tanggal 13 Muharam 1326 H di Sungai Batang, Maninjau, Sumatera Barat. 
pihak kakeknya tercatat nama Syekh Guguk Kuntur atau Abdullah Saleh, beliau adalah putra menantu dari Syekh Abdul Arif yang terkenal sebagai ulama penyebar agama Islam di Padang Panjang pada permulaan abad XIX Masehi dan juga terkenal sebagai salah seorang dari pahlawan perang Paderi. Syekh Abdul Arif yang bergelar Tuanku Pauh Pariaman atau Tuanku Nan Tua. ${ }^{10}$

Kecintaannya terhadap pencarian ilmu membawa HAMKA menjadi sosok yang gemar dalam menulis buku untuk menuangkan ide atau gagasan yang muncul dari buah pemikirannya tentang Islam dan masyarakat, baik itu dalam bentuk sastra maupun bentuk tulisan lain. Karya-karya HAMKA tersebut adalah sebagai berikut: ${ }^{11}$ 1) Antara Fakta dan Khayal "Tuanku Rao"; 2) Beberapa Tantangan terhadap Ummat Islam di Masa Kini; 3) Dari Lembah Cita-Cita; 4) Kisah Nabi-Nabi; 5) Kenangan-Kenangan Hidup Jilid I, II, III, 1V; 6) Lembaga Hikmat; 7) Pandangan Hidup Muslim; 8) Pelajaran Agama Islam; 9) Pribadi; 10) Perkembangan Kebatinan di Indonesia. 11) Said Jamaluddin al-Afghany (Pelopor Kebangkitan Muslimin); 12) Tanya-Jawab Jilid I-II; 13) 1001 Soal-soal Hidup; 14) Di Bawah Lindungan Ka'bah; 15) Margaretta Gauthioer (terjemahan); 16) Bohong di Dunia; 17) Sejarah Ummat Islam Jilid I, II, III, IV; 18) Di dalam Lembah Kehidupan; 19) Tenggelamnya Kapal van Der Wijck; 20) Si Sabariah; 21) Tasawwuf Modern; 22) Ayahku; 23) Kenang-kenangan Hidup I, II, III, dan IV; 24) Empat bulan di Amerika, Jilid I dan II; 25) Pengaruh Ajaran Muhammad Abduh di Indonesia; 26) Dari Perbendaharaan Lama; 27) Falsafah Ideologi Islam (1950); 28) Cita.-cita Kenegaraan dalam Ajaran Islam; 29) Tafsir al-Azhar.

Pengabdian HAMKA terhadap ilmu pengetahuan terutama terhadap keseriusan dirinya menekuni bidang sejarah, dinyatakan dengan bukunya Sejarah Umat Islam. Perhatian HAMKA terhadap sejarah melalui bukunya tersebut, memiliki kecenderungan atau bersinggungan dengan pandangan sejarah merupakan

${ }^{10}$ HAMKA, Kenang-kenangan Hidup, Jilid I (Jakarta: Bulan Bintang,1974), h. 14. Haji Abdul Karim Amrullah lahir pada tanggal 17 Safar 1296 Hijriah atau 10 Februari 1879 M di kampong Kepala Kabun, Jorong Betung Panjang, Nagari Sungai Batang, Sumatera Barat, HAMKA lahir dari istri ketiga yang bernama Syafi'ah dengan nemiliki tiga saudara kandung yaitu Buya Abdulkudus, Asma (perempuan) dan Abdulmu'thi. Lihat: HAMKA. Ayahku: Riwayat Hidup DR H. Abd. Karim Amrullah dan Perjuangan Kaum Agama di Sumatera (Jakarta: Wijaya, 1958), h. 44.

${ }^{11}$ Ris'an Rusli, “Agama dan Manusia dalam Pendidikan HAMKA (Studi Falsafat Agama)”, Intizar, Vol. 20, No. 2, 2014, h. 210. Ris'an Rusli melanjutkan bahwa menilai kepemimpinan dan intelektualitas HAMKA tidaklah mudah. Sebab dunianya sangat luas, baik dalam dunia pendidikan, politik dan dakwah Islam. Dari sisi tulisannya, sebagai umpama, paling tidak tercatat 118 judul buku yang membahas berbagai masalah teologi, filsafat, tasawuf, pendidikan, roman, peradaban dan sejarah, keadilan, perempuan, kebatinan, kenegaraan dan tafsir yang menjadi karya monumentalnya. 
bagian dari politik, atau sejarah adalah politik. Kecenderungan tersebut muncul tidak hanya berada pada tataran sejarah dalam pandangan HAMKA, akan tetapi dimunculkan (diperkuat dengan) pandangan-pandangan politik HAMKA dalam menafsirkan ayat-ayat al-Qur'an pada sebagai ayat di dalam Tafsir al-Azhar.12

Pandangan sejarah HAMKA yang lekat dengan politik dilatarbelakangi oleh kehidupan berorganisasi dan berpolitik HAMKA dengan aktif di Muhammadiyah bahkan membidani berdirinya Muhammadiyah pada tahun 1925. HAMKA terdaftar sebagai anggota Sarekat Islam pada 1925 M, dengan pelantikan dirinya pada 1947 M, dan sebagai ketua Barisan Pertahanan Nasional sekaligus anggota Konstituante Masyumi. ${ }^{13}$

Dorongan pandangan sejarah HAMKA yang lekat dengan segi politik terutama terhadap permaslahan pemimpin dan kepemimpinan umat merupakan refleksi dari kedekatan dirinya dengan kegiatan berorganisasi di Muhammadiyah dan berpolitik di Masyumi. Sejarah dibentuk oleh pemimpin yang memiliki kepemimpinan dengan klasikasi berdasarkan keturunan, kekuatan, kepandaian serta pemimpin lain mengakuinya sebagai pemimpin. ${ }^{14}$

HAMKA memberikan pandangan bahwa pemimpin dan kepemimpinan dijanjikan Allah telah menjelaskan dengan terang dan tanpa berselindung bahwa perkara yang membentuk pimpinan ialah tiga yaitu Allah, rasul dan orang yang beriman, mereka adalah merupakan saluran yang akan menyalurkan kehendak Allah dan rasul dalam mengemudi umat serta mencapai reda Allah. ${ }^{15}$

HAMKA seorang ulama multidimensi, hal itu tercermin dari gelar-gelar kehormatan yang disandangnya. Dia bergelar "Datuk Indomo" yang dalam tradisi Minangkabau berarti pejabat pemelihara adat istiadat. Dalam pepatah Minang, ketentuan adat yang harus tetap bertahan dikatakan dengan "sebaris tidak boleh hilang, setitik tidak boleh lupa". Gelar ini merupakan gelar pusaka

${ }^{12}$ Lihat: Abdul Wahid, "Sosial Politik dalam Tafsir HAMKA," Part 4: Islamic Spirituality, Philosophy \& Tasawwuf, Conference Proceedings - ARICIS I, No 1 (2016). Abdul Wahid memberikan contoh keterkaitan penafsiran HAMKA terhadap keterikatan kehidupan atau lingkungan yang mempengaruihi turunannya ayat melalui surat al-Nisa [4]; 59 dan 58.

${ }^{13}$ Slamet Pramono, "Pandangan HAMKA tentang Konsep Jihad dalam Tafsir al-Azhar", Dialogia Jurnal Studi Islam dan Sosial, Vol 13, No. 2 (2015), h. 111.

${ }^{14}$ HAMKA, Pemimpin dan Pimpinan (Kuala Lumpur: Pustaka Melayu Baru \& Pustaka Budaya Agensi, 1973), h. 3-4.

${ }^{15}$ HAMKA, "Dari Hati Ke Hati: Konsepsi al-Qurān tentang Pemimpin”, Panji Masyarakat, Jakarta: Yayasan Nurul Islam 1971, No. 76, 1 April 1971, h.3-4. 
turun temurun pada adat Minangkabau yang didapatnya dari kakek dari garis keturunan ibunya; Engku Datuk Rajo Endah Nan Tuo, Penghulu suku Tanjung.16

\section{Filsafat Sejarah HAMKA}

HAMKA memiliki keunikan dalam menggambarkan sejarah sebagai sebuah runtutan peristiwa yang tumbuh dan berkembang bersamaan dengan tumbuh dan berkembangannya suatu masyarakat, terutama masyarakat Islam. Tauhid, akhlak, akal menjadi titik tolak bagaimana filsafat sejarah HAMKA berkembang, ketiga unsur-unsur tersebut menjadi titik penting dalam historiografi HAMKA yang tidak muncul serta merta tanpa melalui proses pembelajaran dan perenungan panjang dalam pencarian ilmu yang ditempuh HAMKA.

\section{Tauhid}

HAMKA menyatakan bahwa, pandangan hidup muslim adalah tauhid, sehingga semua aktivitas hidup berdasar padanya, termasuk di dalamnya akhlak atau moral, sebagaimana pernyataannya sebagai berikut:

Sungguh kepercayaan tauhid yang ditanamkan demikian rupa melalui agama yang diajarkan oleh Nabi Muhammad membentuk akhlak penganutnya. Akhlak yang tabah dan teguh. Sebab tidak ada tempat takut, tidak ada tempat menyerah, tempat berlindung melainkan Allah. Akhlak yang teguh ini dikuatkan lagi oleh suatu pokok kepercayaan, yaitu takdir, segala sesuatu dialam ini, sejak dari kejadian langit dan bumi, sampai kepada makhluk yang sekecil-kecilnya, adanya dengan ketentuan dan jangka (waktu). Hidup pun menurut jangka (waktu), mati pun menurut ajal. ${ }^{17}$

${ }^{16}$ Badruzzaman Busyairi, Mengenang 100 Tahun HAMKA Uakarta: Yayasan Pendikikan Islam alAzhar, 2008), h. 2. Sebagai ulama Minang, HAMKA digelari "Tuanku Syaikh", berarti ulama besar yang memiliki kewenangan keanggotaan di dalam rapat adat dengan jabatan Imam Khatib menurut adat. Budi Caniago menyampaikan sebagai pejuang, HAMKA memperoleh gelar kehormatan "Pangeran Wiroguno" dari Pemerintah RI. Sedangkan sebagai intelektual Islam, HAMKA memperoleh gelar "Ustadziyyah Fakhriyyah" (Doctor Honoris Causa) dari Universitas al-Azhar, Mesir, pada Maret 1959. Pada 1974 gelar serupa diperolehnya dari Universitas Kebangsaan Malaysia. Pada upacara wisuda di gedung parlemen Malaysia, Tun Abdul Razak, Rektor Universitas Kebangsaan yang waktu itu menjabat sebagai Perdana Menteri menyebut ulama karismatik itu dengan "Promovendus Professor Doctor HAMKA".

${ }^{17}$ HAMKA, Dari Hati ke Hati tentang Agama, Sosial Budaya, Politik (Jakarta: Pustaka Panjimas, 2002), h. 13. Dalam soal keimanan, HAMKA mengambil posisi yang jelas dan tidak setengahsetengah. Terhadap aliran-aliran yang menyimpang dari ajaran Islam, HAMKA pun memberikan respons yang tegas. Dalam buku Pelajaran Agama Islam misalnya, HAMKA membahas secara panjang lebar aliran Baha'iyah dan Ahmadiyah. Kesimpulan tegas yang ditariknya adalah bahwa setiap orang yang mengaku sebagai nabi setelah Rasulullah adalah seorang pendusta, sedangkan 
Tauhid dan akhlak memiliki hubungan erat, karena tauhid menyangkut aqidah dan keimanan, sedangkan akhlak yang baik menurut pandangan Islam, haruslah berpijak pada keimanan. Iman tidak cukup sekedar disimpan didalam hati, tetapi harus dilahirkan dalam perbuatan nyata dan dalam bentuk amal saleh. Jika keimanan melahirkan amal saleh, barulah dikatakan iman itu sempurna karena telah direalisasikan. ${ }^{18}$

Fuad Mochammad Fachruddin memaknai tauhid sebagai sebuah kepercayaan dalam Islam berdasarkan kepada keharusan berkeyakinan atas kebenaran apa yang dipercayai itu dan benar serta wajar tempat kepercayaan itu menurut pikiran yang waras. Kepercayaan yang berdasarkan keyakinan itu, bertempat di kalbu seseorang. Kepercayaan yang demikian tidak tercapai dengan sempurna dan lengkap syarat-syaratnya, apabila tidak bersandarkan pikiran yang sehat, tidak ada kepercayaan yang kenal apabila tidak bersandarkan akal pikiran, sebagai organ of knowledge. ${ }^{19}$

Tauhid bagi HAMKA bukan hanya sebagai pedoman dalam memaknai kehidupan dalam ruang lingkup habl min Allāh, yang berorientasi pada kesadaran akan kekuasaan Allah, perwakilan makna lā ilāha illa Allāh, melainkan pula makna habl min '-nās yang mengedepankan kesalehan sosial dalm menjalankan apa yang dimaksud dengan khalifah fi ' l-ard. Kedua hubungan ini menuntun manusia mencapai kesempurnaan iman, iman tidaklah sempurna bila dibangun hanya untuk meninggikan Allah tanpa diiringi oleh upaya untuk memberikan kebahagian, kesejahteraan, kemakmuran dan keadilan bagi manusia, serta penghuni bumi sebagai tempat manusia bertindak untuk memenuhi tugasnya tersebut.

\section{Akhlak}

Akhlak menjadi salah satu bagian penting bagi HAMKA dalam menulis sejarah, penulisan sejarah melalui pendekatan ini dilakukan melalui dua cara.

\footnotetext{
yang mengikutinya juga termasuk orang-orang yang mendustakan Rasulullah. Oleh karena itu, baik para nabi palsu tersebut maupun para pengikutnya tidak lagi bisa dinyatakan sebagai umat Muhammad. Baca: Akmal Syafril, "HAMKA tentang Toleransi Beragama," Islamia Jurnal Pemikiran Islam Republika, 15 Desember 2011, h. 25.

${ }^{18}$ Muhammad Alfan, Filsafat Etika Islam (Bandung: Pustaka Setia, 2011), h. 66.

${ }^{19}$ Fuad Mochammad Fachruddin, Filsafat dan Hikmat Sjari'at Islam (Djakarta: Bulan Bintang, 1966), h. 34 .
}

JURNAL THEOLOGIA — Volume 28, Nomor 2, Desember 2017 
Cara pertama adalah dengan mengumpulkan fakta-fakta dari segala macam sumber. Fakta-fakta yang dikumpulkan itu bisa jadi fakta yang dapat diterima akal ataupun fakta yang tidak masuk akal. Menurut cara yang pertama ini, yang paling penting adalah kualitas moral pencerita atau periwayat. Riwayat yang bersumber dari orang yang diketahui pernah berdusta atau curang, dianggap lemah atau palsu. Cara seperti ini pada awalnya digunakan oleh para perawi atau kolektor hadis. ${ }^{20}$ Cara kedua adalah dengan mengumpulkan data dan kemudian menganalisis serta memberi pendapat terhadap data yang terkumpul itu. Menurut HAMKA, cara kedua ini digunakan oleh Ibn Khaldun. Dalam karya tulisnya, termasuk dalam Tafsir al-Azhar, HAMKA tampaknya menggunakan cara kedua ini. ${ }^{21}$

Akhlak menjadi titik penting HAMKA mengedepankan sosok pemimpinpemimpin Islam baik itu bergelar khalifah, sultan amir/emir dalam historiografinya atau meminjam ungkapan Yahya Harun penulis sejarah heroworship, dengan kecenderungan pemimpin Islam dituntun oleh al-Qur'an dan al-Hadis yang menjadi pedoman bagi setiap tindakan dalam menentukan kebijakan bagi kemaslahatan umat, yang salah satu bagian dari kedua rujukan umat Islam tersebut berbicara mengenai keutamaan akhlak. ${ }^{22}$

Pandangan HAMKA ini menunjukkan bahwa pemimpin Islam tidak dapat dilepaskan dari kesalehan individu diri pribadinya, dengan kesalehan yang ditunjukkan melalui upaya memberikan kemaslahatan bagi umat. Kemaslahatan tidak serta merta melepaskan kewajiban untuk melihat bagaimana cara-cara yang ditempuh untuk mewujudkan kemaslahatan itu. Kemaslahatan harus ditempatkan pada tepat yang adil atau proporsional (proporsionalitas), penempatan yang adil dimaksudkan menghindari penggunaan kata maslahat yang terlalu mudah untuk melegitimasi, atau membenarkan pada setiap perbuatan yang ditunjukkan untuk kebaikan umat dapat diperlakukan sebagai suatu kemaslahatan dalam konsep Islam atau bila meminjam istilah uṣūl al-fiqh dengan konsep maṣlahah al-mursalah.

${ }^{20}$ Deliar Noer, "Yamin dan HAMKA: Dua Jalan Menuju Identitas Indonesia", dalam Anthony Reid \& David Marr (Ed.), Dari Raja Ali Haji Hingga HAMKA: Indonesia dan Masa Lalunya, terj. Th Sumarthana (Jakarta: Grafiti Pers, 1983), h. 50.

21 Ibid., h. 50.

${ }^{22}$ Akhlak menjadi titik penting dalam ajaran Islam, dikarenakan salah satu fungsi dari diutusnya Nabi Muhammad ke dunia adalah untuk memperbaiki dan menyempurnakan akhlak manusia yang telah jauh melenceng dari ajaran Nabi Ibrahim as. Atau yang dikenal dengan ajaran haniff. 
Pandangan HAMKA mengenai akhlak yang menggabungkan kesalehan individu dan kesalehan sosial lekat dengan konsep al-Ghazali yang diungkapkan dalam kitab Ihyā' al-'Ulūm al-Dīn, dengan manifestasi akhlak terbentuk dari keadaan-keadaan sebagai berikut: ${ }^{23}$

a. Akhlak berarti perubahan bentuk berbagai jiwa dan sifat-sifat buruk menjadi sifat-sifat baik yang melekat terhadap watak ulamā', shuhadā', șiddīqīn, dan nabi-nabi.

b. Akhlak baik atau terpuji memberikan dorongan terhadap keseimbangan antara tiga kekuatan dalam diri manusia berupa kekuatan berpikir, kekuatan hawa nafsu, dan kekuatan amarah.

c. Akhlak merupakan jalan kebiasaan dari jiwa yang berada tetap dan tidak akan berubah di dalam diri manusia. Akhlak dengan mudahnya akan muncul tanpa perlu berfikir, dikarenakan muncul dan tumbuh dari tindakantindakan dan perilaku manusia. Akhlak terpuji kan muncul dari tindakan dan perilaku indah dan terpuji, dan sebaliknya akhlak buruk akan mumcul dari tindakan dan perilaku buruk dan keji.

d. Lukisan hati seseorang tercermin dari perilaku yang ditampak oleh dirinya.

e. Kepribadian manusia condong kepada kepribadian baik yang menerima pembentukan dari luar dirinya. Pembentukan kepribadian yang baik dipengaruhi oleh kemampuan dalam menerima hal-hal yang baik dengan bersumber pada Kebenaran itu disebut kebenaran pengetahuan (mu'amalah), yaitu pengetahuan yang dapat ditulis secara sistematis dan berhubungan dengan kata-kata yang dapat diterima dan dipelajari orang lain. Adapun kebenaran abstrak berada dalam ide, transenden yang ia disebut pengetahuan (mukashafah). Pengetahuan ini sulit ditembus kata-kata dan tidak dapat dijangkau akal. ${ }^{24}$

${ }^{23}$ HAMKA, Tasauf, Perkembangan dan Pemurniannya (Jakarta: Yayasan Nurul Islam, 1981), h. 123-139. Lihat juga: Enok Rohayati, "Pemikiran al-Ghazali Tentang Pendidikan Akhlak", TA'DIB, Vol. XVI, No. 01, Edisi Juni 2011. Enok Rohayati melanjutkan al-Ghazali memaknai akhlak bukan merupakan "perbuatan", bukan "kekuatan", bukan "ma'rifah" (mengetahui dengan mendalam). Yang lebih sepadan dengan akhlak itu adalah "hal" keadaan atau kondisi: di mana jiwa mempunyai potensi yang bisa memunculkan dari padanya manahan atau memberi. Jadi akhlak itu adalah ibarat dari " keadaan jiwa dan bentuknya yang bathiniah".

${ }^{24}$ Agus Salim Lubis, "Konsep Akhlak dalam Pemikiran al-Ghazali”, Hikmah, Vol. VI, No. 01 Januari 2012, h. 102.

JURNAL THEOLOGIA — Volume 28, Nomor 2, Desember 2017 
f. Jiwa itu dapat dilatih, diskusi, diubah, kepada etika yang mulia dan terpuji. Tiap sifat tumbuh dari hati manusia memancarkan akibatnya kepada anggota tubuh. 25

Akhlak merupakan pembimbing utama dari sikap kebatinan keagamaan yang lazim dikenal dengan tasawuf. Tasawuf berupaya membentuk watak manusia yang memiliki sikap mental dan perilaku yang baik (akhlak alkarimah). Tasawuf ingin membentuk manusia yang bermoral dan memiliki etika serta sopan santun, baik terhadap diri pribadi, orang lain, lingkungan dan Tuhan. Hal ini dapat diawali dari pembersihan batin (esoterik). Sebab seperti yang telah disebutkan di atas bahwa hati adalah pokok utama dalam diri manusia. 26

Akhlak dalam pandangan HAMKA melalui historiografi Sejarah Umat Islam merujuk/ditunjukkan dengan pengungkapan pribadi Nabi Muhammad yang memiliki keluhuran sifat dan sikap. Sifat dan sikap yang luhur ini tidak hanya diungkapkan oleh HAMKA sebagai seorang muslim yang dipengaruhi oleh sosok Nabi Muhammad, melainkan pula diungkapkan oleh para orientalis seperti Voltaire yang memberikan penghargaan secara luar biasa atas peran khātim alanbiy $\bar{a}^{\prime}$ dalam membentuk masyarakat yang digambarkan sebagai masyarakat yang terasing dari pusat peradaban di Timur (Persia) dan Barat (Romawi) ${ }^{27}$

\section{Akal}

HAMKA mengungkapkan akal merupakan petunjuk bagi kehadiran manusia sebagai al-hayawān al-nātiq, yang memiliki fungsi untuk membedakan antara haq dan bāțil, dalam menentukan tindakan yang akan dilakukan. dalam agama Islam memberi kesempatan kepada seseorang untuk menggunakan kemampuan akalnya untuk berfikir dengan maksud untuk mencari dan menemukan kebenaran. Syarat yang mesti terpenuhi dalam pencarian kebenaran menurut HAMKA, dengan membebaskan diri dari syahwat keduniawian yang berlebihan atau dalam istilah lain memperturutkan hawa nafsu amarah. $^{28}$

\footnotetext{
25Yatimin Abdullah, Pengantar Studi Etika (Jakarta: Rajawali Press, 2006), h. 528.

${ }^{26}$ M. Amin Syukur, TasawufKontekstual (Yogyakarta: Pustaka Pelajar, 2012), h.2.

${ }^{27}$ Anonim.

${ }^{28}$ HAMKA, Tafsir al-Azhar, Juz III, (Jakarta: Pustaka Panjimas, 1986), h. 22.
} 
Akal dalam pandangan Hamka tidak dapat berdiri serndiri atau menafikan hubungannya dengan syar'i atau aturan hukum Allah swt yang melekat dengan manusia. Hubungan ini muncul untuk mengukur akhlaq seorang manusia terhadap manuisa yang lainnya, serta terhadap Allah. ${ }^{29}$

HAMKA menunjukkan bahwa akal sebagai pemberian Tuhan memiliki fungsi sebagai pembedaan dengan makhluk ciptan Allah lainnya, akal mempunyai hubungan dengan akhlak, akal memiliki kebebasan untuk mencari, walaupun wilayah pencarian akal itu hanya sebatas wilayah yang dapat di jangkaunya. Menurut HAMKA, dengan akal itu manusia mempunyai kecerdasan, dan kecerdasan itulah yang memberikan kemampuan untuk menilai dan mempertimbangkan dalam pelaksanaan berbagai macam perbuatan manusia sehari-hari. ${ }^{30}$

HAMKA memberikan sebuah pandangan yang akal merupakan representasi dari kesempurnaan pengetahuan yang tertuang dalam makna ilmu, akan tetapi akal tidak dapat memimpin sepenuhnya terhadap suatu ilmu. Akal perlu didukung atau berpedoman pada ajaran agama, keduanya memiliki keterkaitan dalam mengungkap peristiwa-peritiwa yang berlangsung di alam dunia serta peristiwa-peristiwa yang terjadi terhadap manusia sebagai khalifah fil-ard. HAMKA lebih jauh menunjukkan bahwa tujuan saling membutuhkan antara akal dan agama untuk menemukan kebenaran mutlak. Ilmu untuk bendanya. Agama untuk jiwanya. Akal untuk memperkuatkan iman beragama, dan agama untuk memberi arah mulia dari akal.31

${ }^{29}$ HAMKA, Akhlaqul Karimah (Jakarta: Pustaka Panjimas, 1992), h. 4.

${ }^{30}$ HAMKA, Pelajaran Agama Islam (Jakarta: Bulan Bintang, 1984), h. 184.

${ }^{31}$ Abdul Rahman Abdul Aziz, "Nilai Mencapai Kehidupan Sejahtera: Pandangan HAMKA," Jurnal MALIM Bil. 10 (2009), h. 137. Pandangan ini diperdalaman oleh HAMKA bahwa seseorang dapat bahagia apabila bersanding dengan agama. Seseorang akan bahagia apabila ada 'itikad, yakin, iman dan agama. 'Itikad mimiliki pikiran yang dapat dijadikan pijakan seseorang. Pertama 'itikad berbeda dengan keyakinan. Jika seseorang memiliki 'itikad bahwa hal tersebut harus dikerjakan, maka orang tersebut mengerjakan. Sebaliknya apabila harus meninggalkan, maka ditinggalkan. Kedua yakin tidak ragu-ragu. Seorang yakin pada sesuatu karena telah memiliki bukti yang meyakinkan baik empiris atau non empiris. Ketiga iman atau percaya. Iman memiliki makna yakin dihati diucapkan di lisan dan dikerjakan di anggota badan. Keempat agama. Seseorang beragama karena ada 'itikad, yakin, dan iman. Seseorang yang telah menganut agama dengan 'itikad, iman dan yakin yang kuat, maka orang tersebut akan bahagia dengan keadaannya. Orang tersebut akan mendapatkan kepuasan hidup dengan keadaannya. Orang tersebut akan menemukan makna hidup dengan keadaannya. Walaupun orang lain mengatakan tidak masuk akal, menderita, miskin, namun dia meyakini, 'itikad dan beriman dalam satu agama maka orang tersebut akan bahagia. Baca: Saliyo, 
HAMKA mempertegas bagaimana akal berperan besar terhadap diri manusia sebagai al-hayawān al-nāțiq (hewan yang berfikir), melalui akal manusia dapat menjalankan fungsinya sebagai pemeliharan dunia, yang mampu membedakan perilaku atau tindakan baik dan buruk. Akal membimbing manusia untuk bertindak secara arif dan bijaksana, atau lebih tepatnya menempatkan proporsionalitas dalam setiap keputusan yang diambil dalam menentukan baik buruknya suatu keadaan dan tindakan. Manusia melihat alam dengan panca indranya, maka menggetarlah yang kelihatan atau yang kedengaran itu kedalam jiwa. Maka tergambarlah bekasnya itu di dalam jiwa dan menjadi kenangan. Dengan melihat dan mendengar, tergambar dan mengenang itulah manusia membentuk persediaanya menempuh hidup. Dengan itu pulalah ia dapat mengenal mana yang baik dan/ buruk, mana yang jelek dan mana yang indah. ${ }^{32}$

Akal dalam pandangan HAMKA dapat diartikan pula dengan kedudukan manusia yang memiliki jiwa rasional yang hanya dimiliki bangsa manusia saja. Jiwa rasional ini memungkinkan manusia mampu mengambil premis-premis rasional yang berguna untuk membimbing, mengatur, dan menguasai dayadaya dari jiwa-jiwa yang lebih rendah. Manusia merupakan inti dari alam semesta, dan tidak heran kaum bijak menyebut manusia sebagai mikrokosmos karena mengandung semua unsur yang terdapat dalam makrokosmos (alam semesta). Manusia menempati posisi yang istimewa karena manusia dikaruniai roh oleh Allah yang menjadikan manusia memiliki dua dimensi yang membentuk sebuah entitas diri (al-nafs) sebagai sosok yang memiliki tanggungjawab tidak hanya di dunia melainkan di akhirat sebagai konsekuensi manusia beriman. ${ }^{33}$

“Mencari Makna Hidup Dengan Jalan Sufi di Era Modern”, Esoterik: Jurnal Akhlak dan Tasawuf Volume 2 Nomor 12016, h. 122.

${ }^{32}$ HAMKA, Pelajaran Agama Islam, h. 182. HAMKA memelihara sebaik-baiknya hubungan antara wahyu dan akal, serta ilmu riwāyah dan dirāyah. HAMKA tidak hanya mengutip atau menukilkan pendapat ulama terdahulu semata-mata, tetapi beliau juga membuat beberapa tinjauan dalam konteks semasa serta mengambil dari pengalamannya sendiri. Beliau juga tidak menuruti pertimbangan akal semata-mata, sehingga lari dari apa yang dinukilkan oleh khazanah tradisi terdahulu.

${ }^{33}$ Ernita Dewi, "Konsep Manusia Ideal dalam Perspektif Suhrawardi," Substantia, Volume 17 Nomor 1, April 2015, h. 46. 
HAMKA memelihara sebaik-baiknya hubungan antara wahyu dan akal, serta ilmu riwāyah dan dirāyah. HAMKA tidak hanya mengutip atau menukilkan pendapat ulama terdahulu semata-mata, tetapi beliau juga membuat beberapa tinjauan dalam konteks semasa serta mengambil dari pengalamannya sendiri. HAMKA yang memandang akal menjadi bagian penting manusia untuk melihat dan merenungi setiap peristiwa-peristiwa yang mempengaruhi setiap kehidupan manusia, tidak sepenuhnya bergantung kepada kemampuan akal yang dianggap menjadi tolak ukur untuk menilai berbagai peristiwa tersebut. wahyu menjadi bagian terpenting dalam pandangan HAMKA terhadap suatu kejadian, pertimbangan wahyu menjadi rujukan utama bagi HAMKA dimaksudkan untuk tidak lari dari apa yang dinukilkan oleh khazanah tradisi terdahulu. ${ }^{34}$

HAMKA menunjukkan secara terang dan jelas hubungan yang erat antara akal dan wahyu (syar'i), yang diambil pemahaman HAMKA terhadap al-Qur'an., dengan ungkapan:35

Al-Qur'an pun sangat menganjurkan mempergunakan akal dan pikiran buat merenung segala keajaiban alam itu. Maka adalah manusia-manusia istimewa, yaitu yang berilmu pengetahuan kerana dapat mengetahui agak sejemput kecil daripada rahsia alam yang tersembunyi itu... Dalamkan sedikit lagi renungan atas gerak alam itu. Mengapa Matahari ini tidak pernah terjatuh, mengapa bintang-bintang tidak pernah berkisar? Bola disepakkan anak-anak melanjung tinggi ke udara, akhirnya kembali juga ke bawah. Sebab ringan dia terapung ke atas, sebab berat ia turun ke bawah. Mengapa matahari dan bulan tetap begitu saja, tidak pernah jatuh ke bawah, padahal diapun berat? Sebanyak itu bintang di langit, tak terhitung, tak sekali juga berlaga, tak sekali juga berbentur di antara satu sama lain..

\section{Penutup}

Filsafat sejarah HAMKA mengarahkan bahwa Tauhid, Akhlak, dan Akal merupakan bagian yang tidak terpisahkan dalam melihat suatu peristiwa yang kemudian dikenal dengan sejarah. Tauhid ditujukkan dengan keberserahan manusia sebagai makhluk Allah bahwa peristiwa yang terjadi kepada manusia

${ }^{34}$ Abdul Rouf, Mohd Yakub, Zulkifli Mohd Yusoff, "Tafsir al-Azhar dan Tasawuf Menurut HAMKA", Jurnal Usuluddin, Vol 38, Juli - Desember 2013, h. 11

35Zul'Azmi Yaakob, "Falsafah Alam dalam Konteks Falsafah Ketuhanan Menurut HAMKA', International Journal of Islamic Thought Vol. 1, June 2012, h. 75. Lihat juga: Hamka, Filsafat Ketuhanan (Melaka: Penerbitan Abbas Bandong, 1979), h. 30-31. 
merupakan keadaan yang semestinya terjadi, walaupun dalam peristiwa tersebut terdapat peran manusia sebagai subjek yang menyebabkan munculnya peritiwa itu terjadi. Tauhid yang dimaknai kepasrahan tidak menghilangkan sisi peran manusia.

Aspek akal menjadi penentu bahwa tidak setiap peristiwa dimaknai sebagai takdir yang apa adanya. Akal manusia yang menunjukkan kemampuan diri makhluk sebagai ahssan al-taqwìm dapat menentukan bagaimana suatu peristiwa dapat ditentukan arahnya. Penentuan arah peristiwa ini didasarksn pada penggunaan akal material, akal naluri, akal aktif dan akal mustafad sebagaimana yang diungkapkan oleh al-Ghazali.

Akhlak menjadi aspek ketiga yang membentuk filsafat sejarah HAMKA sebagai satu kesatuan yang tidak terpisahkan. Akhlak membentuk manusia dalam memahami suatu peristiwa tidak hanya ditentukan oleh sisi Tauhid dan Akal, melainkan diiringi pula oleh Akhlak yang memiliki fungsi untuk mengatur perilaku manusia bagaimana seharusnya bersikap dalam setiap peristiwa sejarah, dengan maksud untuk memeperoleh 'ibrah (pelajaran).]

\section{DAFTAR PUSTAKA}

Alfan, Muhammad, Filsafat Etika Islam, Bandung: Pustaka Setia, 2011.

Amir, Mafri dan Kultsum, Lilik Ummi, Literarur Tafsir Indonesia, Lembaga Penelitian UIN Syarif Hidayatullah Jakarta, Ciputat, 2011.

Aziz, Abdul Rahman Abdul, "Nilai Mencapai Kehidupan Sejahtera: Pandangan HAMKA," Jurnal MALIM Bil. 10, 2009.

Busyairi, Badruzzaman, Mengenang 100 Tahun HAMKA, Jakarta: Yayasan Pendikikan Islam al-Azhar, 2008.

Dewi, Ernita, "Konsep Manusia Ideal dalam Perspektif Suhrawardi", Substantia, Volume 17 Nomor 1, April 2015.

Fachruddin, Fuad Mochammad, Filsafat dan Hikmat Sjari'at Islam, Djakarta: Bulan Bintang, 1966. 
HAMKA, Ayahku: Riwayat Hidup DR H. Abd. Karim Amrullah dan Perjuangan Kaum Agama di Sumatera, Jakarta: Wijaya, 1958.

__ "Dari Hati Ke Hati: Konsepsi al-Qurân tentang Pemimpin", Panji Masyarakat, Jakarta: Yayasan Nurul Islam 1971, No. 76, 1 April 1971.

_. Pemimpin dan Pimpinan, Pustaka Melayu Baru \& Pustaka Budaya, Kuala Lumpur: Agensi, 1973

Kenang-kenangan Hidup, Jilid I, Jakarta: Bulan Bintang,1974.

Sejarah Umat Islam IV, Jakarta: Bulan Bintang,1976.

Tasauf, Perkembangan dan Pemurniannya, Jakarta: Yayasan Nurul Islam, 1981.

Pelajaran Agama Islam, Jakarta: Bulan Bintang,1984.

Tafsir al-Azhar Juz III, Jakarta: Pustaka Panjimas, 1986.

Akhlaqul Karimah, Jakarta: Pustaka Panjimas, 1992

Dari Hati ke Hati tentang Agama, Sosial Budaya, Politik, , Jakarta: Pustaka Panjimas, 2002.

al-Khateeb, Firas, Lost Islamic History Reclaiming Muslim Civilisation From The Past, London: Hurst Publisher, 2014.

Lubis, Agus Salim, "Konsep Akhlak dalam Pemikiran al-Ghazali," Hikmah, Vol. VI, No. 01 Januari 2012.

Noer, Deliar, "Yamin dan HAMKA: Dua Jalan Menuju Identitas Indonesia", dalam Anthony Reid \& David Marr (Ed.), Dari Raja Ali Haji Hingga HAMKA: Indonesia dan Masa Lalunya, terj. Th Sumarthana, Grafiti Pers, Jakarta, 1983.

Rohayati, Enok, "Pemikiran al-Ghazali tentang Pendidikan Akhlak," TA'DIB, Vol. XVI, No. 01, Edisi Juni 2011.

Rouf, A., Yakub, M., Yusoff, Z. M., "Tafsir al-Azhar dan Tasawuf Menurut HAMKA", Jurnal Usuluddin, Vol 38, Juli - Desember 2013.

Rusydi, Pribadi dan Martabat Buya Prof. Dr. HAMKA, Jakarta: Pustaka Panjimas, 1983. 
Saliyo, "Mencari Makna Hidup Dengan Jalan Sufi di Era Modern," Esoterik: Jurnal Akhlak dan Tasawuf, Volume 2 Nomor 12016.

Sardiman, dkk, "Buya HAMKA dan Perkembangan Muhammadiyah (19251981)”, Laporan Penelitian, Fakultas Ilmu Sosial Universitas Negeri Yogyakarta, 2012.

Shalih Ahmad ats-Tsamy, Min Ma'in al-Sirah, Beirut: al-Maktab al-Islamy, 1984.

Shafiyu al-Rahman al-Mubarakafury, Rahiq al-Makhtum Bahthun al-Sirah alNabawiyyah 'alā Ṣāhibuhā Af̣̣alu al-Ṣalātu wa 'l-Salām, al- Mansurah: Dar al-Wafa, 2002.

Slamet Pramono, "Pandangan HAMKA Tentang Konsep Jihad dalam Tafsir alAzhar", Dialogia Jurnal Studi Islam dan Sosial, Vol 13, No. 2, 2015.

Syafril, Akmal, "HAMKA tentang Toleransi Beragama," Islamia Jurnal Pemikiran Islam Republika, 15 Desember 2011.

Syukur, M. Amin, Tasawuf Kontekstual, Yogyakarta: Pustaka Pelajar, 2012.

Umar, A. Muin, Historiografi Islam, Jakarta: Rajawali Press, 1988.

Yakub, M., "Historiografi Islam Indonesia: Perspektif Sejarawan Informal," MIQOT Vol. XXXVII No. 1 Januari-Juni 2013.

“Perkembangan Islam Indonesia,” Kalam, Volume 7, Nomor 1, Juni 2013.

Wahid, Abdul, "Sosial Politik dalam Tafsir HAMKA", Part 4: Islamic Spirituality, Philosophy \& Tasawwuf, Conference Proceedings - ARICIS I, No 1, 2016.

Yahya Harun, Islam Nusantara Abad XVI \& XVII, Kurnia Kalam Sejahtera, Yogyakarta, 1995.

Zul'Azmi Yaakob, "Falsafah Alam dalam Konteks Falsafah Ketuhanan Menurut HAMKA”, International Journal of Islamic Thought, Vol. 1, June 2012. 